\title{
Nové britské směrnice o léčbě hypertenze
}

\author{
Jiří Widimský \\ Klinika kardiologie, Institut klinické a experimentální medicíny, \\ Subkatedra kardiologie IPVZ, Praha, Česká republika
}

Pracovníci Národního institutu pro zdraví a klinickou kvalitu (National Institute for Health and Clinical Excellence - NICE) ${ }^{(1)}$ ve spolupráci s Britskou společností pro hypertenzi uveřejnili 28. června 2006 aktualizaci klinických doporučení léčby hypertenze.

Jejich hlavní změnu lze vidět $\mathrm{v}$ tom, že vyřazují betablokátory jako léky první volby u nekomplikované hypertenze. Rozhodnutí, že betablokátory nebudou použivány v léčbě první volby u nekomplikované hypertenze, se opírá o důkazy prokazující jejich nižší účinnost v léčbě hypertenze, zejména u starších pacientů a dále jako průkaz toho, že betablokátory $\mathrm{v}$ běžně použivaných dávkách zvyšují riziko vzniku nového diabetes mellitus 2 . typu.

Nicméně i podle těchto směrnic zůstávají betablokátory plně indikovány u všech pacientů po infarktu myokardu a $\mathrm{u}$ pacientů $\mathrm{s}$ anginou pectoris. Betablokátory vykazují totiž u nemocných po infarktu myokardu kardioprotektivní účinek. Ten byl demonstrován u nemocných po infarktu myokardu celou řadou studií. ${ }^{(2)}$ Kardioprotektivní účinek je způsoben arytmickým působením - betablokátory zvyšují totiž fibrilační práh a patři kromě amiodaronu $\mathrm{k}$ jediným antiarytmikưm použivaným úspěšně $u$ nemocných v léčbě komorových arytmií a u nemocných se srdečním selháním. Náhlou smrt u nemocných po infarktu myokardu snižují betablokátory v průměru o $32 \%$ (metaanalýza 25 dlouhodobých studií léčby nemocných po infarktu myokardu betablokátory. ${ }^{(3)}$

Důležitý je i jejich antiischemický účinek, který je způsobený zpomalením tepové frekvence, poklesem krevního tlaku a snížením srdeční kontraktility. Tyto tř̀ parametry určují totiž spotřebu kyslíku v myokardu.

Důležitý je též bradykardizující vliv vedoucí k prodloužení diastolické doby plnění. Koronární průtok se totiž odehrává především v diastole. Délka diastolické periody je tedy velice důležitá $\mathrm{v}$ patogenezi ischemie.

Betablokátory snižují u nemocných po infarktu myokardu výskyt náhlé smrti, snižují výskyt reinfarktů i celkovou mortalitu. Prokázaly to četné studie provedené vesměs $\mathrm{v}$ době před rozšířením revaskularizační léčby akutního infarktu myokardu. Náhlou smrt u nemocných po infarktu myokardu snižují betablokátory průměrně o $32 \%$ (metaanalýza 25 dlouhodobých studií léčby nemocných po infarktu myo-

Adresa: prof. MUDr. Jiří Widimský, DrSc., FESC, ČLA, Klinika kardiologie, IKEM, Vídeňská 1958/9, 14021 Praha 4, Česká republika, e-mail: widimsky@seznam.cz kardu betablokátory). ${ }^{(3)}$ U nemocných s anamnézou srdečního selhání v akutní fázi infarktu myokardu byl účinek betablokátorů ještě větší.

Existence kardioprotektivního účinku betablokátorů byla prokázána studií CAPRICORN 2001(4) i v době léčby akutního infarktu myokardu revaskularizací (PCI, trombolytická léčba).

Příznivý účinek betablokátorů $u$ nemocných po infarktu myokardu však neposkytuji všechny betablokátory. ${ }^{(5)}$ Metaanalýza klinických studií betablokátorů s placebovou skupinou ${ }^{(5)}$ ukázala, že důkazy o snížení celkové mortality u nemocných po infarktu myokardu existují pouze $\mathrm{v}$ případě metoprololu (relativní riziko 0,80; 95\% CI 0,66-0,90), propranololu (relativní riziko 0,$71 ; 95 \%$ CI $0,59-0,85$ ), timololu (relativní riziko 0,71 ; 95\% CI 0,46-0,77), ale již neexistují u atenololu, tak často používaného kardioselektivního betablokátoru $\mathrm{v}$ klinické praxi. Atenolol nesnižuje celkovou mortalitu u nemocných po infarktu myokardu ani ve srovnání s placebem!!!(5) Nevhodné jsou rovněž u nemocných po infarktu myokardu betablokátory s ISA (pindolol, oxprenolol).

$Z$ této analýzy vyplývá, že $\mathrm{v}$ léčbě nemocných po infarktu myokardu bychom měli dávat přednost především metoprololu, protože propranolol a timolol nejsou na našem trhu. Existuje také jedna studie svědčící pro příznivý účinek acebutololu - studie APSI $^{(6)}$ u nemocných po infarktu myokardu. Takže $z$ betablokátorů, jež jsou na našem trhu, bychom $\mathrm{u}$ pacientů po infarktu myokardu měli použivat pouze metoprolol a acebutolol.

Další trvalou indikací betablokátorů i v britských směrnicích je chronické srdeční selhání a systolická dysfunkce levé komory u hypertenze i u pacientů bez hypertenze. Betablokátory vedou $\mathrm{k}$ prevenci srdeční remodelace a podle řady velkých studií významně a výrazně snižují i celkovou mortalitu nemocných s chronickým srdečním selháním. ${ }^{(7-9)}$ Tyto studie musely být vesměs předčasně ukončeny pro přiznivý účinek betablokátorů. Betablokátory snižují mortalitu nemocných se srdečním selháním o 36 \%. Kombinace léčby inhibitory ACE s betablokátory má pak největší vliv na celkovou mortalitu, nebot' ji snižuje o $46 \%$.

U některých nemocných dochází vlivem léčby betablokátory téměř $\mathrm{k}$ normalizaci ejekční frakce levé komory - jde o mladší nemocné s častým výskytem dilatační kardiomyopatie, vyšším krevním tlakem a méně pokročilou systolickou dysfunkcí levé komory. 
Studie COPERNICUS ${ }^{(9)}$ prokázala, že carvedilol dokáže zlepšit prognózu i nejtěžších nemocných ve stadiu NYHA III-IV. Studie COPERNICUS ${ }^{(9)}$ byla předčasně ukončena pro velmi příznivé výsledky. Celková mortalita byla carvedilolem snížena o 36 \%. Pokles mortality byl patrný ve všech podskupinách pacientů rozdělených podle věku, pohlaví, ejekční frakce levé srdeční komory nebo diagnózy (ICHS nebo dilatační kardiomyopatie). Léčba carvedilolem byla dobře snášena a výskyt přerušení léčby pro nežádoucí účinky byl ve skupině léčené carvedilolem dokonce nižší než ve skupině léčené placebem.

Někteří lékaři se chybně domnivají, že léčba betablokátory je neúčinná u diabetiků nebo u starších osob, zejména osob starších než 70 let. Není tomu tak; v podskupinách diabetiků nebo starších nemocných se srdečním selháním byly betablokátory uvedeny jako stejně účinné u mladších nemocných nebo $\mathrm{u}$ nemocných bez diabetu.

Katecholaminy bývají totiž u chronického srdečního selhání zvýšeny a existuje dokonce korelace mezi stupněm tohoto zvýšení a srdeční prognózou. Betablokátory mohou omezovat proarytmogenní vliv selhávajícího myokardu. Betablokátory také snížily výskyt náhlé smrti u nemocných s chronickým srdečním selháním. Možným mechanismem proto může být snížení toxického vlivu katecholaminů na myokard vlivem betablokátorů. Betablokátory omezují též „přestřelení“ neurohumorálních adaptačních mechanismů při srdečním selhání.

Betablokátory omezují též „přestřeleni““ neurohumorálních adaptačních mechanismů při srdečním selhání. Mohou omezovat i pokles hustoty betareceptorů, jež mají za následek, že na daný stimulus, například emoci, reaguje srdce menším zvýšením tepové frekvence i tepového výdeje.

Ve studiích CIBIS II a MERIT-HF zemřelo náhlou smrtí $47 \%$ a $64 \%$ nemocných. Snížení výskytu náhlých úmrtí představuje důležitý mechanismus účinku betablokátorů.

Dosud je však kombinací inhibitorů ACE a betablokátorů léčeno v evropském programu IMPROVEMENT of $\mathrm{HF}^{(10)}$ průměrně $20 \%$ nemocných s chronickým srdečním selháním v Evropě a 25 \% v České a Slovenské republice; v programu Euro Heart Failure Survey ${ }^{(1)}$ dokonce jen $17,2 \%$ nemocných s chronickým srdečním selháním. Jinými slovy čtyři pětiny nemocných s chronickým srdečním selháním v Evropě a třri čtvrtiny nemocných v České a ve Slovenské republice nejsou správně léčeny! Tento nedostatek je způsoben především malým použiváním betablokátorů.

Léčba chronického srdečního selhání v České a Slovenské republice je na evropské úrovni včetně jejich nedostatků. ${ }^{(12)}$

Úmyslně jsme rozvedli indikace betablokátorů, které zůstávají v platnosti. Velký rozruch provázející uveřejnění britských směrnic by mohl vést $\mathrm{k}$ opuštění léčby betablokátory i v těchto důležitých indikacích, které i podle britských směrnic zůstávají v platnosti.

Změny léčby hypertenze se týkají především pacientů s nízkými riziky, jež mají nekomplikovanou hypertenzi, tj. hypertenzí, kterou neprovázejí přidružená onemocnění, $\mathrm{k}$ nimž patří ischemická choroba srdeční nebo chronické srdeční selhání nebo asymptomatická systolická dysfunkce levé komory.

Betablokátory by neměly být podle britských směrnic léky první volby v léčbě nekomplikované hypertenze. Carlberg a spol. upozornili v metaanalýze $\mathrm{v}$ roce $2004,{ }^{(14)}$ ve které porovnali účinek atenololu $\mathrm{s}$ placebem v léčbě hypertenze, na jejich minimální účinnost. Carlberg a spol. ${ }^{(14)} \mathrm{v}$ této metaanalýze ukázali, že atenolol v léčbě hypertenze nesnižoval celkovou a kardiovaskulární mortalitu dokonce i ve srovnání s placebem, i když krevní tlak snižoval. Výsledky této metaanalýzy ukazuje tabulka I.

Tabulka I

Atenolol v léčbě hypertenze ve srovnání

s placebem nebo ve srovnání se stavem bez léčby; metaanalýza $(\mathrm{n}=6825 \text { pacientů })^{(14)}$

\begin{tabular}{ll}
\hline \hline Cíl & Relativni riziko \\
\hline Celková mortalita & $1,01(95 \%$ CI $0,89-1,15)$ \\
Kardiovaskulární mortalita & $0,99(95 \%$ CI $0,83-1,18)$ \\
Infarkty myokardu & $0,99(95 \%$ CI $0,83-1,19)$ \\
\hline \hline
\end{tabular}

Tabulka II pak porovnává atenolol ve srovnání $\mathrm{s}$ jinými antihypertenzivy v léčbě hypertenze.(14)

\section{Tabulka II}

Atenolol v léčbě hypertenze ve srovnání s jinými antihypertenzivy; metaanalýza ( $\mathrm{n}=17671$ pacientů)

\begin{tabular}{ll}
\hline \hline Cil & Relativni riziko \\
\hline Celková mortalita & $1,13(95 \%$ CI $1,02-1,25)$ \\
& statisticky významné \\
Kardiovaskulární mortalita & $1,16(95 \%$ CI $1,00-1,34)$ \\
Cévní mozkové příhody & $1,30(95 \%$ CI $1,12-1,50)$ \\
\hline \hline
\end{tabular}

V této metaanalýze atenolol významně zvyšoval celkovou mortalitu v porovnání s jinými antihypertenzivy a zvyšoval také výskyt cévních mozkových příhod ve srovnání s jinými antihypertenzivy.

Tyto údaje ukazují, že atenolol není vhodným betablokátorem v léčbě hypertenze.

Nicméně se atenolol stale použivá jako oblíbený komparátor v řadě studií. Studie $\operatorname{LIFE}^{(15)}$ například porovnala losartan s atenololem, studie ASCOT-BPLA ${ }^{(16)}$ pak amlodipin \pm perindopril $\mathrm{s}$ atenololem \pm bendroflumethiazidem.

Lindholm a spol. ${ }^{(17)}$ pak provedli metaanalýzu všech studií betablokátorů v léčbě hypertenze. Do metaanalýzy bylo zahrnuto 13 randomizovaných klinických studií porovnávajících betablokátory s jinými antihypertenzivy. Metaanalýza zahrnula 105951 pacientů ve 13 studiích, porovnávajících betablokátory $\mathrm{s}$ jinými antihypertenzivy, a dalších 7 studií porovnávajících betablokátory $\mathrm{s}$ placebem $\mathrm{v}$ léčbě hypertenze. Hlavním výsledkem bylo zjištění, že betablokátory zvyšují relativní riziko cévních mozkových příhod o $16 \%$ ve srovnání s jinými antihypertenzivy. Je však třeba uvést, že většina těchto studií se týkala atenololu, daleko méně metoprololu. Proč většina studií léčby hypertenze si vybrala atenolol, o kterém bylo známo již $z$ metaanalýzy Freemantla a spol. $\mathrm{z}$ roku 1999,(5) že postrádá kardioprotektivní účinek? 
I u pacientů po infarktu myokardu (dokonce při porovnání s placebem) to není autorovi tohoto přehledného článku zcela jasné. Hledal se slabší „sparing“ partner, jak jsem nedávno uvedl $\mathrm{v}$ jiném článku o úskalí „evidence based medicíny”(18)?

Vratme se ale $\mathrm{k}$ britským směrnicím léčby hypertenze. ${ }^{(1)}$ U nekomplikované hypertenze doporučujî nové britské směrnice pouze trri skupiny za léky volby u nekomplikované hypertenze: inhibitory ACE, blokátory kalciových kanálů a thiazidová diuretika.

Zatímco u starších pacientů (nad 55 let) jsou podle těchto směrnic léky volby thiazidová diuretika nebo blokátory kalciových kanálů, u osob mladších než 55 let jsou léky volby inhibitory ACE (blokátory AT1). Tato změna vychází $z$ uvedených metaanalýz demonstrujících malou účinnost betablokátorů $\mathrm{v}$ prevenci cerebrovaskulárních komplikací.

Navíc existuje řada studií prokazujících, že látky ovlivňující renin-angiotenzin-aldosteronový systém brání vzniku nového diabetes mellitus 2. typu ve srovnání s betablokátory a diuretiky, například studie ASCOT-BPLA. ${ }^{(16)}$ Výsledky této studie jsme také komentovali V našem časopise. ${ }^{(19)}$ Studie ASCOT-BPLA prokázala větší účinnost léčby hypertenze opírající se o amlodipin \pm perindopril ve srovnání s léčbou opírající se o atenolol \pm bendroflumethiazid. Nelze rozlišit, do jaké míry to bylo způsobeno poněkud větším poklesem krevního tlaku u nemocných léčených kombinací amlodipin \pm perindopril. Zajímavý se ukázal větší pokles centrálního systolického aortálního tlaku působením této kombinace, jak to ukázala studie CAFE. ${ }^{(20)}$

Nelze však také vyloučit námitku, že atenolol není rozhodně rovnocenným partnerem amlodipinu, jak jsme již v tomto článku ukázali.

Nové britské směrnice vzbudí jistě diskusi. Není zejména jasné, zda všechny betablokátory jsou stejné. Ve většině velkých studií poslední doby byl $z$ betablokátorů použiván jen atenolol. Vzniká tedy otázka, zda například carvedilol, acebutolol a další betablokátory by neposkytovaly podstatně větší ochranu než atenolol.

Betablokátory se také uplatňují v léčbě perioperační hypertenze, v léčbě těhotenské hypertenze a v léčbě tachyarytmií.

Britské směrnice se liší od dosud platných amerických i evropských směrnic. V amerických směrnicích léčby hypertenze ${ }^{(21)}$ jsou u nekomplikované hypertenze thiazidová diuretika léky první volby. Někteři američtî autoři mnohdy uvádějí, že $\mathrm{v}$ budoucích studiích by měla být thiazidová diuretika léčbou volby všech a porovnávaly by se jen kombinace ostatních antihypertenziv, jako léků druhé volby, tj. diuretika + ACE inhibitory vs. diuretika + blokátory kalciových kanálů či AT1 blokátory apod.

Dosud platná verze evropských ${ }^{(22)}$ a českých ${ }^{(23)}$ směrnic považuje všech pět hlavních skupin antihypertenziv za rovnocenné, tj. diuretika, betablokátory, inhibitory ACE, blokátory kalciových kanálů a blokátory AT1. Nová verze evropských a i českých směrnic se však připravuje a otázce léčby nekomplikované hypertenze betablokátory se jistě bude věnovat.

Závěrem lze jistě zpochybnit úlohu betablokátorů v léčbě nekomplikované hypertenze, zejména pak atenololu.

\section{LITERATURA}

1. www.nice.org.uk/CG034NICEguideline.

2. Yusuf S, Peto R, Lewis J, et al. Beta-blockade during and after myocardial infarction: an overview of the randomised trials. Prog Cardiovasc Dis 1985;27: 335-71.

3. Held PH, Yusuf S. Effects of beta-blockers and calcium channel blockers in acute myocardial infarction. Eur Heart J 1993;14 (Suppl F): 18-25.

4. The CAPRICORN Investigators. Effects of carvedilol on outcome after myocardial infarction in patients with left-ventricular dysfunction: the CAPRICORN randomised trial. Lancet 2001;357:1385-90.

5. Freemantle N, Cleland J, Young P, Mason J, Harrison J. Beta-blockade after myocardial infarction: systematic review and meta regression analysis. Br Med J 1999; 318:1730-7.

6. Boissel JP, Leizorovicz A, Picolet H, et al. Efficacy of acebutolol after acute myocardial infarction. (The APSI Trial). Am J Cardiol 1990;66:24C-31C.

7. CIBIS Investigators and Committees. The Cardiac Insufficiency Bisoprolol Study II. (CIBIS-II). Lancet 1999; 353:9-13.

8. MERIT-HF Study Group. Effect of Metoprolol CR/XL in Chronic Heart Failure: Metoprolol CR/XL Randomised Intervention Trial in Congestive Heart Failure (MERIT-HF). Lancet 1999;353:2001-7.

9. Packer M, Fowler MB, Roecker EB, et al. for the Carvedilol Prospective Randomized Cumulative Survival (COPERNICUS) Study Group. Effect of carvedilol on the morbidity of patients with severe chronic heart failure. Results of the Carvedilol Prospective Randomized Cumulative Survival (COPERNICUS) Study. Circulation 2002;106:2194-9.

10. Cleland JGF, Cohen-Solal A, Cosin Aguilar J, et al. for the IMPROVEMENT of Heart Failure Programme Committees and Investigators and the Study Group on Diagnosis of the Working Group on Heart Failure of the European Society of Cardiology. Management of heart failure in primary care (the IMPROVEMENT of Heart Failure Programme): an International Survey. Lancet 2002;360:1631-9.

11. Komajda M, Follath F, Swedberg K, et al. for the Study Group on Diagnosis of the Working Group on Heart Failure of the European Society of Cardiology. The Euro Heart Failure Survey programme - a survey on the quality of care among patients with heart failure in Europe. Part 2: treatment. Eur Heart J 2003;24:464-75.

12. Widimský J, Lánská V, Magulová D, Sachová M. Průzkum stavu aktuální praxe diagnostiky a léčby srdečního selhání v ordinacích všeobecných lékařù v České a Slovenské republice $\mathrm{v}$ roce 1999. 2. část programu IMPROVEMENT of HF. Cor Vasa 2001;54:345-54.

13. Widimský J, Špinar J. Nedostatky léčby srdečního selhání v Evropě. Zaostává klinická praxe za evropskými směrnicemi? Zaostává Česká republika za Evropou? Cor Vasa 2003;45: 481-5.

14. Carlberg B, Samuelsson O, Lindholm LH. Atenolol in hypertension: is it a wise choice? Lancet 2004;364: 1684-9.

15. Dahlöf B, Devereux RB, Kjeldsen SE, et al. for the LIFE study group. Cardiovascular morbidity and mortality in the Losartan Intervention For Endpoint reduction in hypertension study (LIFE): a randomized trial against atenolol. Lancet 2002;359:995-1003

16. Dahlöf B, Sever PS, Poulter NE, et al. for the ASCOT Investigators. Prevention of cardiovascular events with an antihypertensive regimen of amlodipine adding perindopril as required versus atenolol adding bendroflumethiazide as required, in the Anglo-Scandinavian Cardiac Outcomes Trial-Blood Pressure Lowering Arm (ASCOT-BPLA). Lancet 2005;366: 895-906. 
17. Lindholm LH, Carlberg B, Samuelsson O. Should beta blockers remain first choice in the treatment of primary hypertension? A meta-analysis. Lancet 2005;366: 1545-53.

18. Widimský J. Klady a úskalí „evidence based“ medicíny. Cor Vasa 2006;48:24-31.

19. Widimský J, sr. Studie ASCOT-BPLA. Léčba opírající se o amlodipin \pm perindopril poskytuje lepší výsledky než léčba opírající se o atenolol \pm bendroflumethiazid v léčbě hypertenze. Cor Vasa 2005;47:437-40.

20. Williams B, Lacy PS, Tom SM, et al. for the CAFE Steering Committee and Writing Committee. The CAFE Investigators, for the Anglo-Scandinavian Cardiac Outcomes Trial (ASCOT) Investigators. Differential impact of blood pressure-lowering drugs on central aortic pres- sure and clinical outcomes. Circulation 2006;113: 1213-25.

21. The Seventh Report of the Joint National Committee on Prevention, Detection, Evaluation, and Treatment of High Blood Pressure. The JNC 7 Report. JAMA 2003; 289:2560-72.

22. Guidelines Committee. 2003 European Society of Hypertension - European Society of Cardiology guidelines for the management of arterial hypertension. J Hypertens 2003;21:1011-53.

23. Cífková R, Horký K, Widimský J sr., a spol., za Českou společnost pro hypertenzi. Doporučení diagnostických a léčebných postupů $\mathrm{u}$ arteriální hypertenze - verze 2004. Doporučení České společnosti pro hypertenzi. Cor Vasa 2005;47:K3-K16. 